\title{
Germination and Water Content of Cocoa Seeds After Storage Treatments
}

\author{
Indah Anita-Sari ${ }^{1 *}$, Bayu Setyawan ${ }^{1)}$, Febrilia Nur ${ }^{(}$Aini $^{1}{ }^{1}$, and Agung Wahyu Susilo ${ }^{1)}$ \\ ${ }^{1)}$ Indonesian Coffee and Cocoa Research Institute, Jl. PB Sudirman No. 90, Jember 68118, Indonesia \\ ${ }^{*}$ Corresponding author: indah.sari83@yahoo.com \\ Received: 20 September 2018 / Accepted: 15 November 2018
}

\begin{abstract}
The challenge of providing cocoa seeds is the characteristic of recalcitrant seed, thus requiring storage techniques that can slow down the decline in seed viability in an effort to manage the distribution of cocoa seeds which depend to the time of demand and harvest. The research aimed to study the effect of packaging method for storage of cocoa seeds; the effect of shelf life and temperature to germination and water content of seeds, and the stability of seed germination at different age and storage temperature. The research was conducted at Kaliwining Experimental Station, Indonesian Coffee and Cocoa Research Institute, Jember, East Java. The research used complete randomized design with research design using split plot. The treatments consisted of packaging methods, storage temperature and storage life. Packaging methods consisted of two methods, i.e. vacuum methods and non vacuum methods. Storage temperature consisted of three treatments, i.e. $15^{\circ} \mathrm{C}, 25^{\circ} \mathrm{C}$ and $30^{\circ} \mathrm{C}$. both of packaging and temperature treatments were stored at four shelf life treatment included 1 week, 2 weeks, 3 weeks, and 4 weeks. Each treatment was repeated with three replications and each treatment per replication consisted of 50 seeds. Data analysis used SAS 9.0 and stability analysis used R program and PB Tool. Water content of seeds, germination of seeds and number of seedy seeds were observed. The results showed that type of packaging and storage temperature effect to germination of cocoa seeds but did not effect to seeds water content. Storage of cocoa seeds by non-vacuum packaging showed a higher of germination compared to vacuum packaging in all temperature treatments. Storage with non vacuum packaging at a temperature $25^{\circ} \mathrm{C}$ showed a germination more than $85 \%$ for 2 weeks of shelf life, while storage of cocoa seeds at a temperature of $30^{\circ} \mathrm{C}$ had a germination of more than $85 \%$ for only 1 week shelf life. Storage of cocoa seed at $15^{\circ} \mathrm{C}$ showed the lowest of germination at treatment. Storage treatments did not show effect on water content of cocoa seeds.
\end{abstract}

Keywords: Cocoa seeds, germination, packaging, storage, temperature, water content

\section{INTRODUCTION}

Availability of superior cocoa seeds continuously determine the cocoa production in Indonesia. The challenge of providing the superior cocoa seeds is a characteristic of recalcitrant seeds, thus requiring storage techniques that can slow down the decline in seeds viability in an effort to manage the distribution of cocoa seeds depand to the time of demand and harvest. Recalsitrant seeds are characterized by a very short life- 
time, no dormancy period, high water content range 0,4-4,0 g water/gram (Umarani et al., 2015), sensitive to changes in temperature and low humidity (Maemunah et al., 2009), easily loses viability when water content decline below 20-30\% and can not be stored at low temperature near to $0^{\circ} \mathrm{C}$ (Umarani et al., 2015). Recalcitrant seeds also have characters that are not tolerant to desiccation, low temperature, low humidity (Sumampow, 2011), and are sensitive to high and low moisture content (Halimursyadah, 2012). Rahardjo (2011) reported that fresh seed have water content approximately $50 \%$. High initial water content in recalcitrant seeds can activate the seed metabolic process that should not take place and is used as an energy reserve when the seed stored, so that the high initial water content must be reduced until the water content is safe for seed storage (Halimursyadah, 2007). The safe of initial water content of storing cocoa seeds is araound 35-40\% (Rahardjo, 2010). Decreasing the water content of seeds to below the critical water content (12-31\%) can cause the viability of seeds to decrease rapidly, and even cause death (Esrita, 2009). The condition of storage temperature and humidity will affect the seed moisture content during the storage period. The decrease in viability of recalcitrant seeds caused by moisture content is indicated by low germination, low shelf life, increased membrane leakage, cellular damage and biochemical changes in food reserves, low of viability, growth time and dry weight seeds (Robi, 1996). Age of tropical recalcitrant seeds is reported to be quite short and varies from two weeks to several months (Halimursyadah, 2012).

The study of cocoa seed storage that have been done was by modifying the storing atmospheric conditions included temperature, humidity, and physiological causes that affect the potential of seeds storage (Umarani et al., 2015). The modification of oxygen depletion during the storage of cocoa seeds is also reported to slow the declining of seed viability (Rahardjo, 2011). Modification of storage places through packaging is expected to prolong the storage life of cocoa seeds. The reduction of oxygen through vacuum packaging has not been widely reported on cocoa seed storage. Modification of temperature is important to slow the decrease of viability at certain shelf life condition. The critical point of cocoa seeds and other recalcitrant seeds is also influenced by the method of seed packaging, moisture content, and drying methods. The decline of seed is the process of quality purification gradually and can not be reversed (irreversible) due to physiological changes caused by internal factors of the seed. Physiological regression of seed quality is characterized by decreased of seed germination, increased of abnormal seed germinated, decreased of seed viability, stunted seedling growth and increased of seed sensitivity to extreme environments (Purwanti, 2004). The stability of seed viability at shelf life and temperature storage has an impact to the quality of the cocoa seed quality. The stable of viability and water content of seeds will support the development of seed germination that will be produced. The research aimed to study the effect of packaging method for storage of cocoa seeds; the effect of shelf life and temperature to germination and water content of seeds; and the stability of seed germination at different age and storage temperature.

\section{MATERIALS AND METHODS}

The materials used ICCRI 08H hybrid seeds, fungicides, germination box, germination media and plastic packaging. Cocoa seeds were taken from cocoa seeds gardens located at Kaliwining Research Station, Indonesian Coffee and Cocoa Research Institute, Jember, East Java. Seed was taken from the ripe physiologically of pod and done peeling seeds. Before peeling the seeds, seeds 
mixed with sawdust to facilitate stripping. The peeled seeds were the put into a fungicide solution for 5-10 minutes and then dried approximately to $40 \%$ of water content. The dried seeds were then stored on plastic in accordance with the treatment.

The research used complete randomized design with research design using split plot. The treatments consisted of packaging methods, storage temperatures and shelf life. Packaging methods consisted of two methods, i.e. vacuum and non-vacuum methods. Storage temperatures consisted of three treatments, i.e. $15^{\circ} \mathrm{C}, 25^{\circ} \mathrm{C}$, and $30^{\circ} \mathrm{C}$. Both of packaging and temperature treatments were stored at four storage periods included 1 week, 2 week, 3 week and 4 week. Each treatment repeated three replications and each treatment per replication consisted of 50 seeds. Data analysis used SAS 9.0 and stability analysis used $\mathrm{R}$ program and $\mathrm{PB}$ Tool.

Seed water content was observed by the oven methods referring to the method developed by Rahardjo (2011) as follows (1) weighing the preheated porcelain cup (W1, g), (2) weighing the porcelain contained the cocoa seeds (W2, g), (3) the cup containing the seeds was ovenered at $130^{\circ} \mathrm{C}$ for 50 minutes, (4) cooling the porcelain cup and seeds in the exicator for 45 minutes the weighing (W3, g), (5) reheating in the oven for 10 minutes at temperature of $130^{\circ} \mathrm{C}$, (6) cooling into the next indicator weighing (W4, g), (7) on the first heating the percentage of water released, (8) recording the data records and the calculating the water content as follows:

$$
\begin{aligned}
& S 1=\frac{\mathrm{W} 2-\mathrm{W} 3}{\mathrm{~W} 2-\mathrm{W} 1} \times 100 \% \\
& S 2=\frac{\mathrm{W} 3-\mathrm{W} 4}{\mathrm{~W} 2-\mathrm{W} 1} \\
& S W C=S 1+S 2-\frac{S 1 \times S 2}{100}
\end{aligned}
$$

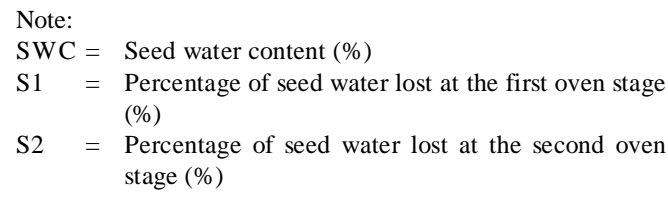

Number of germinated seeds was observed by calculated the seeds was germinated after storage. Viability was observed by calculated the number of germinated seeds after germinate in the germination container with sand planting media. Fourty cocoa seeds was planted with a depth of $2-3 \mathrm{~cm}$ in container and then covered with sand and then placed in a greenhouse. Each treatment was repeated three times. Observations were done for 7 days and observed every day by counting the number of germinating seeds.

\section{RESULTS AND DISCUSSION}

\section{Moisture Content}

The study showed that the water content of cocoa seeds during storage ie 1 to 3 weeks in two packaging methods ie vacuum and nonvacuum did not show significant different. However, at 4 weeks of storage showed the different of seed water content in each treatment. Storage of cocoa seed at temperature $25^{\circ} \mathrm{C}$ and $30^{\circ} \mathrm{C}$ in non-vacuum packaging during 4 weeks had water content to reach $40 \%$. In different packaging (vacuum) with same storage age treatment and stored at $15^{\circ} \mathrm{C}$ and $30^{\circ} \mathrm{C}$ showed an increase of seed water content to reach $50 \%$. Otherwise, when cocoa seeds stored at temperature $25^{\circ} \mathrm{C}$ in vacuum packaging and temperature $15^{\circ} \mathrm{C}$ in non-vacuum packaging showed a decrease of water content to reach $30 \%$ (Figure 1).

Water content in seeds has a function to maintain the structure of seed cells. Decreasing of moisture content in orthodox seeds will not effect to viability, it can even 


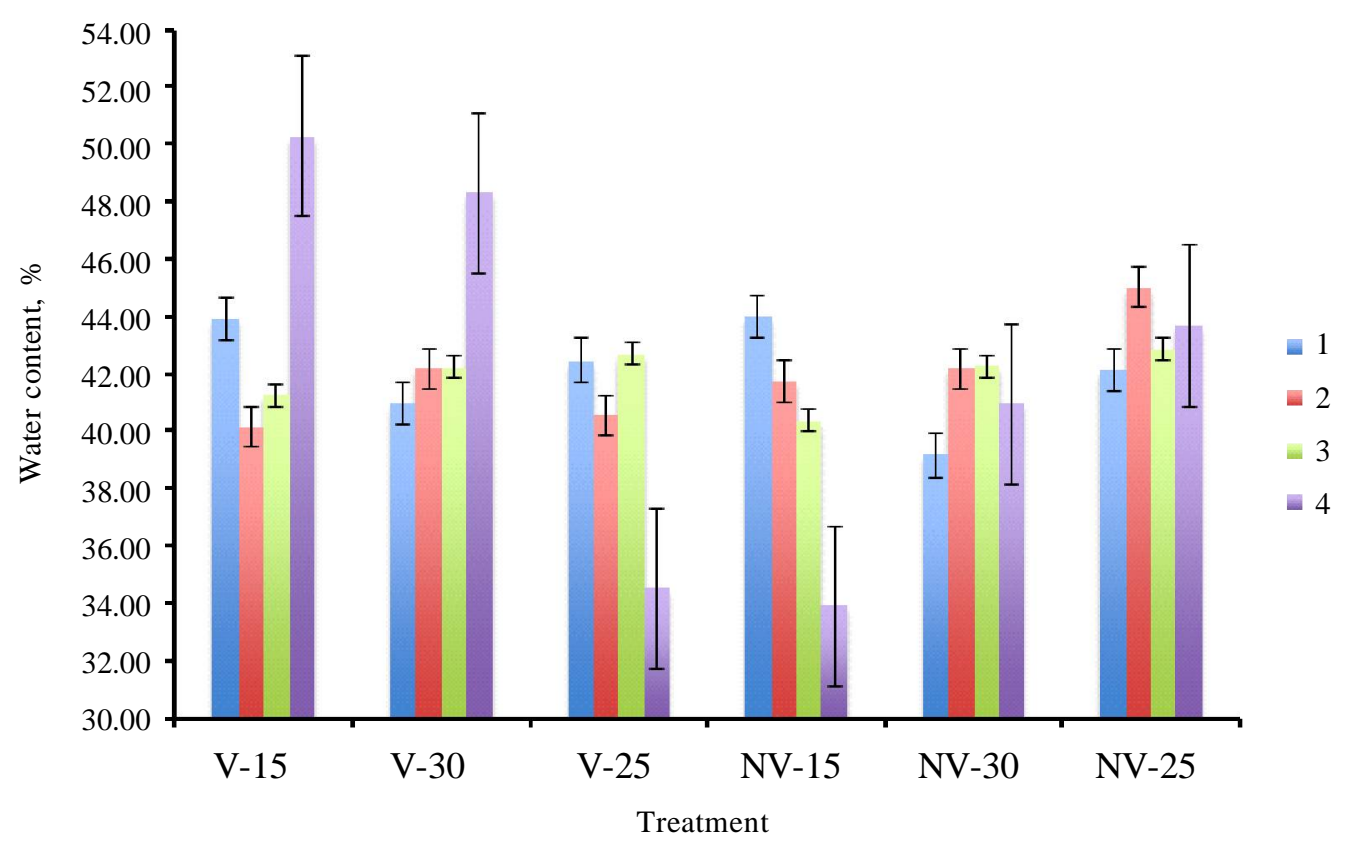

Figure 1. Water content of seeds during storage 1-4 weeks in different packaging methods, storage temperature and shelf life $\left(\mathrm{V}=\right.$ vacuum; $\mathrm{NV}=$ non-vacuum; $15=15^{\circ} \mathrm{C} ; 25=25^{\circ} \mathrm{C} ; 30=30^{\circ} \mathrm{C}$; $1-4=$ storage life on weeks)

increase the storage life. In contrast to recalcitrant seeds, a reduction of water content will cause cellular damage. Recalsitrant seeds stored in relatively humid condition have relatively short shelf life (Halimursyadah, 2012). In line with this study results, seeds stored in temperature $15^{\circ} \mathrm{C}$ in non-vacuum showed a decrease in higher moisture content. In contrast to the vacuum packaging and stored at $30^{\circ} \mathrm{C}$ indicated the addition of seed moisture content. Air humidity has an inverse relationship to air temperature, so that with high air temperature will lead to precipitation (condensation) molecules.

\section{Germinated and Viable Seeds}

Storage of cocoa seeds in non-vacuum packaging at temperature $15^{\circ} \mathrm{C}$ during 4 weeks of storage showed the highest percentage of germinated seeds (Figure 3). The percentage of germinated seeds associated with seeds water content. The low temperature of environment mean it has a high air humidity. Optimum temperature for cocoa seeds germination ranges from $15-30^{\circ} \mathrm{C}$, while maximum temperature is around $35-40^{\circ} \mathrm{C}$ (Copeland, 2001). The development of cocoa seed will quickly occur in high humidity. In line with this study that cocoa seed stored at temperature $15^{\circ} \mathrm{C}$ indicated a higher percentage of germinated seeds than the other temperature treatments (Figure 3).

According to Gairola et al. (2011), germination of seed is affected by the ecological conditions prevailing in the habitat. It depends on several environmental conditions such as temperature, moisture germination media and oxygen content. Seed of certain species have different temperature responses according to variety and provenances and also reasonable to believe that these responses are adaptive success or failure of a population in a particular environment depends on the way 


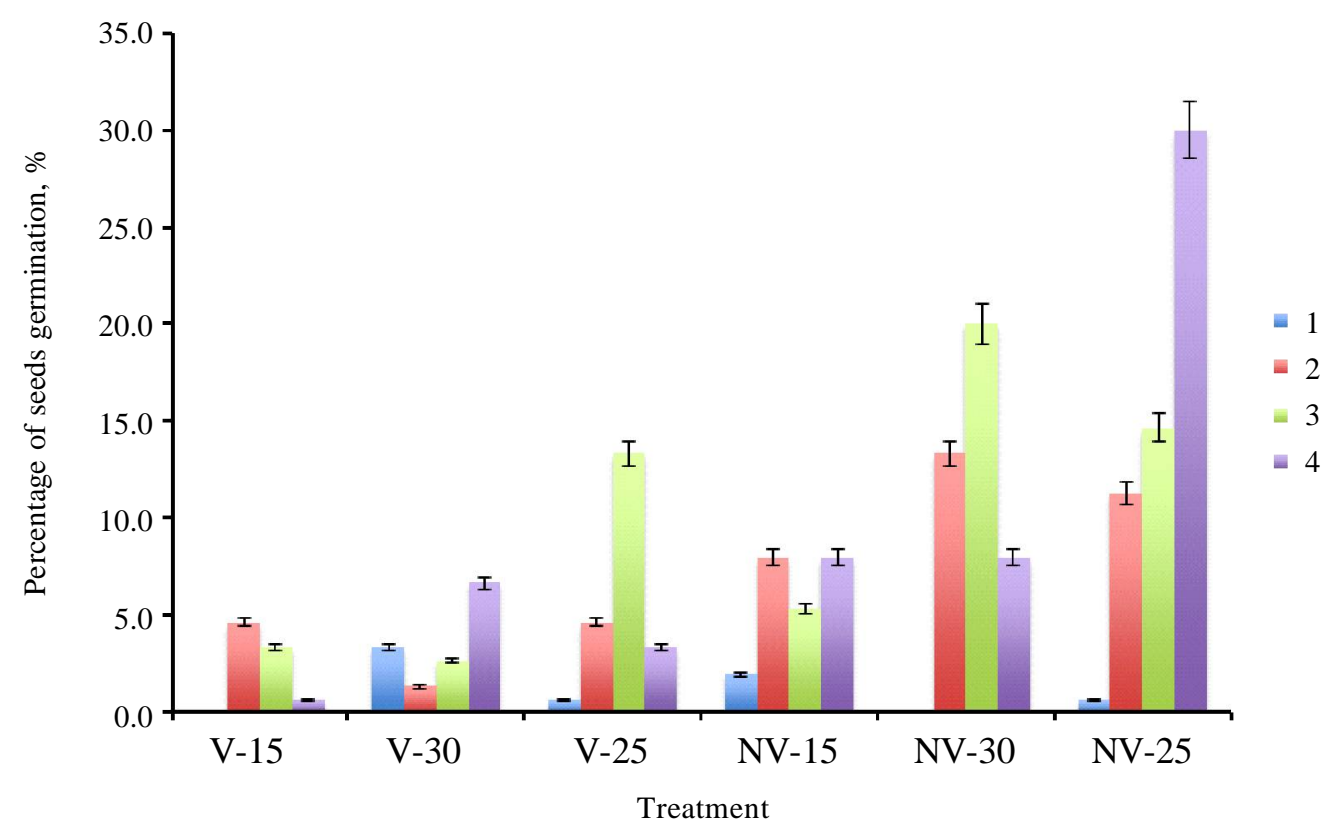

Figure 3. Percentage of germinated seeds on different of packaging, temperatures and shilf life (V = vacuum; $\mathrm{NV}=$ non-vacuum $; 15=15^{\circ} \mathrm{C} ; 25=25^{\circ} \mathrm{C} ; 30=30^{\circ} \mathrm{C} ; 1-4=$ storage life on weeks)

of its germination responses fit in to the ecological conditions of the habitat. Thus in most of the seeds, the rate of germination are strongly governed by temperature. The availability of oxygen during storage will influence the seed condition for fast growing or germination. Storage temperature is one of the factors that influence the seed viability related to environmental moisture. The high temperature will cause in seed damage (Rahman et al., 2014), while the low temperature during storage can suppress the rate of reduced viability of the seed (Sutopo, 2002). Seeds are hygroscopic and always try to achieve aquilibrium conditions with the environment. In the storage room with high humidity than water content of the seeds, seeds will absorb water and seed moisture content increase so it will quickly germinate (Kuswanto, 2003).

The results showed that the storage of cocoa seeds at temperature $25^{\circ} \mathrm{C}$ in vacuum packaging during 1 to 4 weeks of storage had the highest percentage of seed germination.
The germination percentage of cocoa seeds stored at temperature $25^{\circ} \mathrm{C}$ and $30^{\circ} \mathrm{C}$ for one week of storage could reached $100 \%$. The germination percentage of cocoa seeds stored at temperature $30^{\circ} \mathrm{C}$ decreased rapidly when storage for 2 weeks. While the germination percentage of cocoa seeds stored at temperature $25^{\circ} \mathrm{C}$ for 2 weeks of storage could be reached $90 \%$. Storage of cocoa seeds for 3-4 weeks showed decrease of germination percentage of seeds below than $60 \%$. Storage of cocoa seeds at temperature $15^{\circ} \mathrm{C}$ showed the lowest of viability during 1-4 weeks of storage (Figure 4). The seeds have hygroscopic character and always manage to achieve equilibrium condition with the environment. If the seeds environment has higher of moisture than seeds water content, the seed will absorb the water from the air and the seed moisture become increased (Kuswanto, 2003).

Storage of cocoa seeds in non-vacuum packaging, stored at temperature $25^{\circ} \mathrm{C}$ during 1-3 weeks of storage showed the highest of 
germination percentage. Storage of cocoa seeds with similar packaging and stored at $30^{\circ} \mathrm{C}$ showed the highest percentahe of seed germination only one week of storage (Figure 5).

The factors that influence the deterioration rate of seed included oxygen pressure (amount of oxygen with the seeds in storage), seed moisture content, and temperature (Roberts, 1973). Inreasing in any of these factors will lower the shelf life of the seeds, and a general rule any increase of $1 \%$ moisture content or $10^{\circ} \mathrm{F}$ in storage will halve the storage life of the seeds (Bewley \& Black, 1985). Each factor contributes to seed decay in specific ways, and minimizing these conditions is critical to effective seed storage. Schmidt (2000), reported that recalcitrant seeds do not resistant with drying and low storage temperature. Zink \& Rochelle (1964) reported that cocoa seeds were stored at the temperature of $5^{\circ} \mathrm{C}$ was highly injurious to the seeds, while cocoa seeds were stored
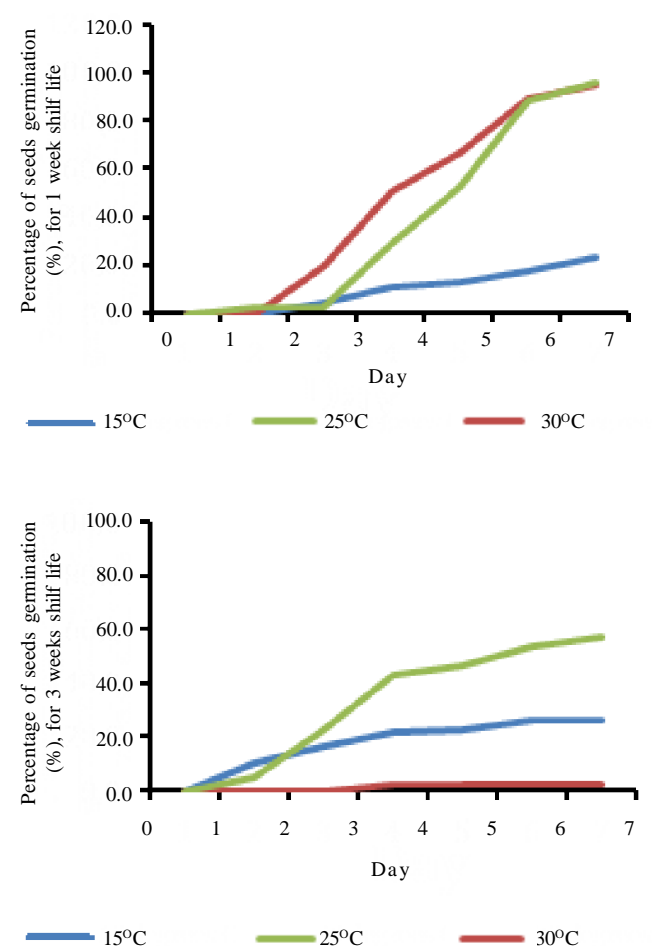

Figure 4. Viability of cocoa seeds on vacuum packing method at different temperatures and shilf lifes

at the temperature of the laboratory under high relative humidity preserved their viability well during all the time of the experiment.

\section{Germination and Seed Water Content}

The results showed that the germination percentage of cocoa seed, both in vacuum and non-vacuum packaging were significantly influenced by storage temperature and shelf life. While, water content of cocoa seeds did not significantly influenced by storage temperature and storage life (Table 1).

Temperature is one of the factor determine the seeds viability. The high of temperature during storage will be cause damage to the seeds. While, the low of temperature during storage can be reducing the rate of seed viability (Sutopo, 2002). Umarani et al. (2015) reported that the storage of recalcitrant seeds in low temperature aims to prevent any oxidation damage accuring during storage. Storage of
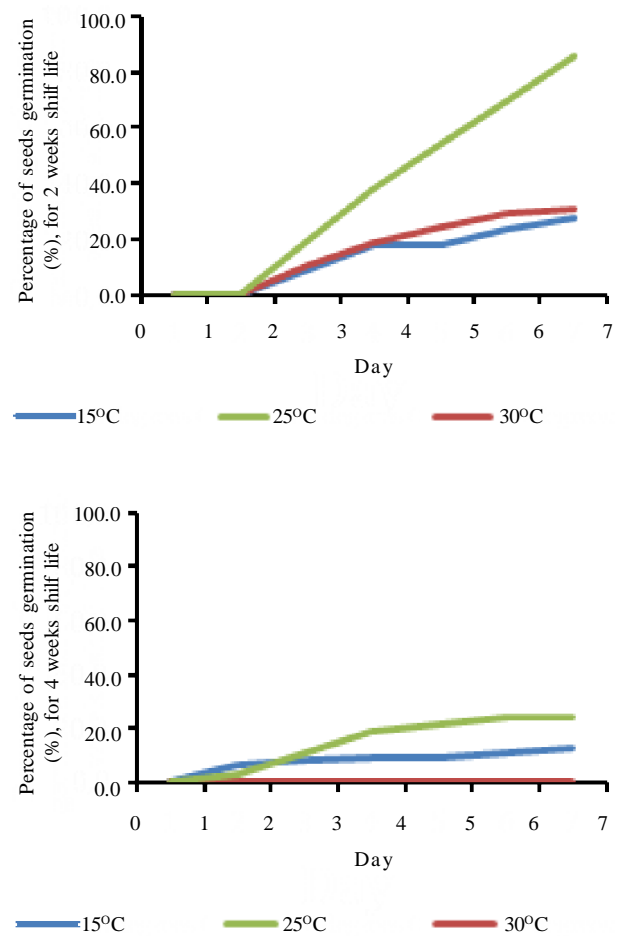

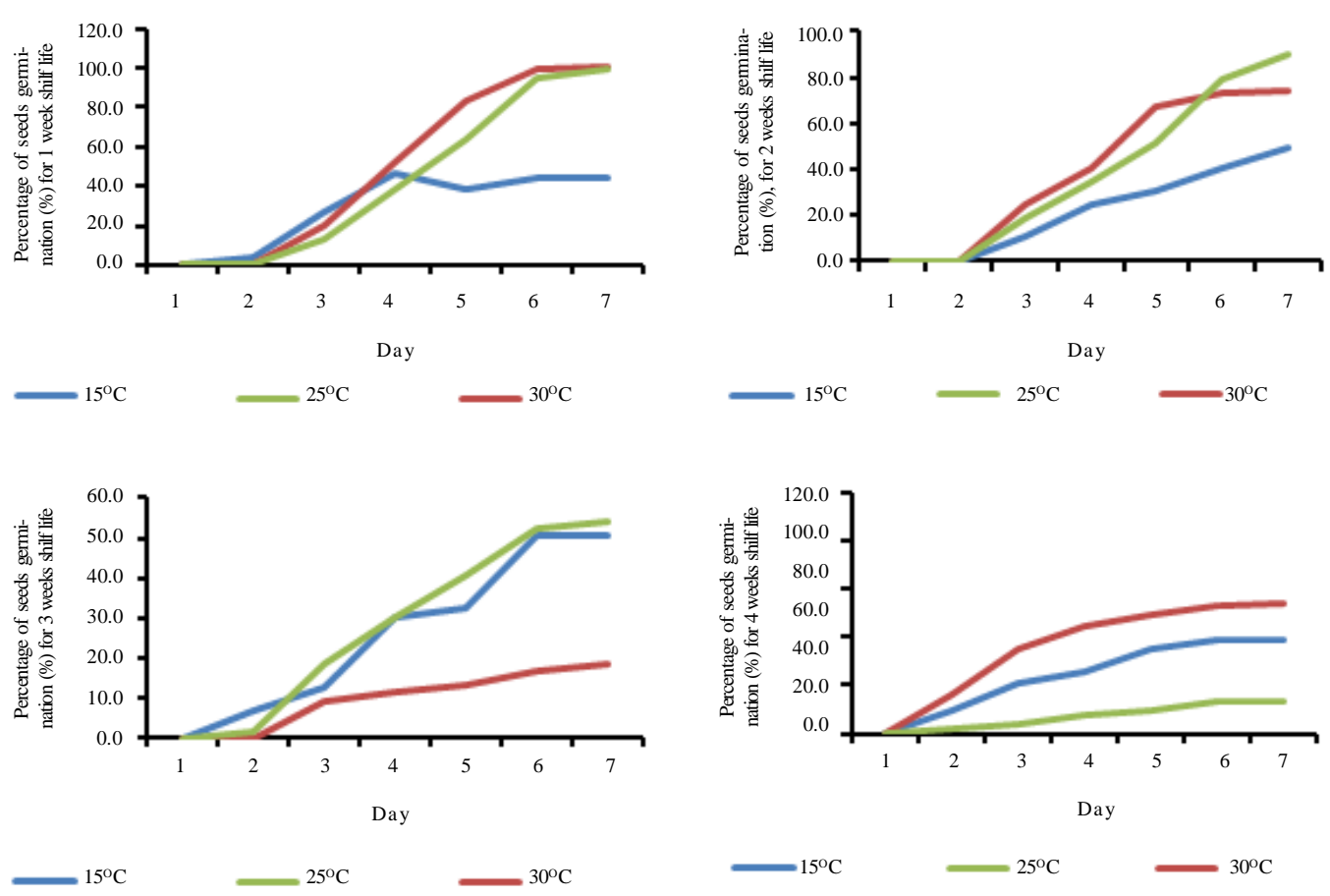

Figure 5. Viability of cocoa seeds in non-vacuum packing method at different temperatures and shilf lifes

recalcitrant seeds at low temperature can decrease damage and minimize the ossociations of seeds with mycoflora. However, the species varies of seeds recalcitrant had different tolerance to temperature. Seed storage at a centain temperature impacts on seed viability. Seed stored below room temperature will influence the seed viability, the seed will germinate above 80 percent after 30 days of storage life. Conversely, seeds are stored at high temperature, the germination of seed will decrease to zero percent.

The results showed that shelf life, temperature storage and packaging types influenced the germination percentage of cocoa seeds, but did not influence the water content of seeds. The highest of germination percentage of seeds showed at temperature $25^{\circ} \mathrm{C}$, while storage of cocoa seed at temperature $15^{\circ} \mathrm{C}$ showed the lowest of germination percentage. One week of storage showed the highest of the germination percentage of cocoa seeds both of vacuum and non-vacuum packing. Sukesh \& Chandrashekar (2013) reported that there was influence of decreasing the temperature to seed germination percentage. There will decrease in seed germination percentage with decrease in the storage temperature, the misture will decrease with storage period. Decreasing of moisture will change in carbohydrate and modification of protein may together responsible for the reduction in the viability of the seeds. Non-vacuum packaging showed a higher of germination percentage of seeds than vacuum packaging in all shelf life treatments (Table 2).

Hasid (2008) reported that seeds distribution and storage could lead to reduce seed viability. Unsuitable packaging, media and storage condition will cause seed moisture content decrease excessively and this causes a drastic decrease in seeds viability and resulting in germination below $50 \%$. Seeds 
storage with high humidity can cause fungal attack at the storage life and cause decrease of seed quality. The low viability and vigor of cocoa seeds is influenced by enzyme activity as a results of low germination rates. Likewise the rate of respiraton decreases with the decline of seeds as a results of membrane damage in the mitochondria (Ilyas, 2010). Enzyme activities correlated with respiration decreased as an expression of the activity of various enzymes that react together in overhauling food reserves so the food reserves in the seeds are reduced and germination decreases (Ilyas, 2001). If the seed has declined during storage, the seed viability will decrease and effect in low production. Ilyas (2010) reported that the physiological deterioration of cocoa seeds after four weeks storage was observed in low rates of germination and seedling growth. Increased seed germination can be conducted by indirectly improving the membrane and encouraging decreased electrolyte leakage (Chang \& Sung, 1998), thus accelerating the appearance of germination earlier (Chiu et al., 2002). Declining of water content of cocoa seed caused declining of seed quality. Water content of seed during storage can be maintained to certain extent by using a storage medium (Sumampow, 2010). Maemunah (2009) reported that one of the effforts to maintain the moisture content of seeds during storage is to adjust the humidity of the storing media using sawdust.
Cocoa seed stored at $25^{\circ} \mathrm{C}$ and $30^{\circ} \mathrm{C}$ both of vacuum and non-vacuum packaging during one week of storage showed the highest of germination percentage of seeds. Cocoa seeds which stored at $25^{\circ} \mathrm{C}$ and $30^{\circ} \mathrm{C}$ for 2 weeks of storage in non-vacuum packing showed slower decrease than in vacuum packing (Table 3).

Seed vigor is reflected by viability and storability of seeds. Both physiological value reflect the ability of seed to grow into normal plants even though the biophysical condition of the suboptimum or after the seeds exceeds a long shelf period (Maemunah et al., 2009). Cocoa seeds are recalcitrant, implying that they are short-lived, and unable to survive desiccation when extracted from the pods (Adu et al., 2016). Loss of viability occurs because the moisture content decreases below the standard value. Three factors that cause the damage to recalcitrant seeds and cause a decrease in viability include mechanical damage, damage due to metabolism and denaturation of macromolecules. Types of damage to recalcitrant seeds under specific storage conditions is caused by changes in biochemical damage to recalcitrant seeds caused by high seed water content. Two mechanism for the seed quality reduction are microorganism during the storage and fungi that damage the seeds through exocelluler enzymes and toxins (Ilyas, 2010).

Tabel 1. Germination percentage of cocoa seeds in different packaging methods, storage temperature and shelf life

\begin{tabular}{|c|c|c|c|c|c|}
\hline \multirow{3}{*}{ SV } & \multirow{3}{*}{$\mathrm{df}$} & \multicolumn{4}{|c|}{ MS } \\
\hline & & \multicolumn{2}{|c|}{ Vacuum } & \multicolumn{2}{|c|}{ Non-vacuum } \\
\hline & & Germination & $\begin{array}{c}\text { Moisture } \\
\text { content }\end{array}$ & Germination & $\begin{array}{c}\text { Moisture } \\
\text { content }\end{array}$ \\
\hline Temperature & 3 & $5301.09^{* *}$ & $55.07 \mathrm{~ns}$ & $1618.75^{* *}$ & $187.11^{\mathrm{ns}}$ \\
\hline Replication & 8 & $198.26^{\mathrm{ns}}$ & $44.36 \mathrm{~ns}$ & $910.93^{*}$ & $102.47^{\mathrm{ns}}$ \\
\hline Shelf life & 2 & $5800.69^{* *}$ & $9.18^{\mathrm{ns}}$ & $3954.39^{* *}$ & $124.09 \mathrm{~ns}$ \\
\hline Temperature *life & 6 & $1696.06^{* *}$ & $63.7^{\text {ns }}$ & $2203.01^{* *}$ & 89.26 ns \\
\hline
\end{tabular}

Note: $\mathrm{ns}=$ not significantly difference; $*$ significantly at $\alpha=0.05 ; * *=$ significantly at $\alpha=0.01$. 
Table 2. Percentage of cocoa seed germinated and moisture content in vacuum and non-vacuum packaging on different storage temperature and shelf life

\begin{tabular}{lcccc}
\hline & \multicolumn{2}{c}{ Vacuum packing } & \multicolumn{2}{c}{ Non-vacuum packing } \\
\cline { 2 - 5 } & Germination $(\%)$ & $\begin{array}{c}\text { Moisture } \\
\text { content }\end{array}$ & $\begin{array}{c}\text { Germination }(\%) \\
\text { Moisture } \\
\text { content }\end{array}$ \\
\hline Temperature & & & & \\
$15^{\circ} \mathrm{C}$ & $23.54 \mathrm{~b}$ & $43.58 \mathrm{a}$ & $42.92 \mathrm{~b}$ & $40.23 \mathrm{a}$ \\
$25^{\circ} \mathrm{C}$ & $65.63 \mathrm{a}$ & $39.72 \mathrm{a}$ & $64.17 \mathrm{a}$ & $47.45 \mathrm{a}$ \\
$30^{\circ} \mathrm{C}$ & $33.54 \mathrm{~b}$ & $43.27 \mathrm{a}$ & $61.67 \mathrm{a}$ & $41.07 \mathrm{a}$ \\
Shelf life & & & \\
1 week & $71.39 \mathrm{a}$ & $42.77 \mathrm{a}$ & $77.22 \mathrm{a}$ & $42.05 \mathrm{a}$ \\
2 week & $48.05 \mathrm{~b}$ & $40.93 \mathrm{a}$ & $71.11 \mathrm{a}$ & $48.26 \mathrm{a}$ \\
3 week & $28.33 \mathrm{c}$ & $42.00 \mathrm{a}$ & $41.11 \mathrm{~b}$ & $41.69 \mathrm{a}$ \\
4 week & $15.83 \mathrm{c}$ & $43.35 \mathrm{a}$ & $35.55 \mathrm{~b}$ & $39.67 \mathrm{a}$ \\
\hline Note: Mean of each variable that followed by same letter not significanly different based on Duncan multiple range test at
\end{tabular}

Tabel 3. Interaction of packing methods, temperature, and shelf life to percentage of cocoa seed germinated and water content

\begin{tabular}{|c|c|c|c|c|c|}
\hline \multirow{2}{*}{$\begin{array}{l}\text { Temperature } \\
\left({ }^{\circ} \mathrm{C}\right)\end{array}$} & \multirow{2}{*}{$\begin{array}{l}\text { Shelf life } \\
\text { (week) }\end{array}$} & \multicolumn{2}{|c|}{ Vacuum packing } & \multicolumn{2}{|c|}{ Non-vacuum packing } \\
\hline & & $\begin{array}{c}\text { Germination } \\
(\%)\end{array}$ & $\begin{array}{c}\text { Water content } \\
(\%)\end{array}$ & $\begin{array}{c}\text { Germination } \\
(\%)\end{array}$ & $\begin{array}{c}\text { Water content } \\
(\%)\end{array}$ \\
\hline 15 & 1 & 23.33 defg & $43.91 \mathrm{~b}$ & 49.17 cde & $44.17 \mathrm{~b}$ \\
\hline 15 & 2 & 27.50 defg & $40.12 \mathrm{~b}$ & 48.17 cde & $41.67 \mathrm{~b}$ \\
\hline 15 & 3 & 25.83 defg & $41.27 \mathrm{~b}$ & 50.83 cde & $40.37 \mathrm{~b}$ \\
\hline 15 & 4 & $12.50 \mathrm{fg}$ & $49.04 \mathrm{ab}$ & 39.17 def & $34.40 \mathrm{~b}$ \\
\hline 25 & 1 & $95.83 \mathrm{a}$ & $42.55 \mathrm{~b}$ & $99.17 \mathrm{a}$ & $42.12 \mathrm{~b}$ \\
\hline 25 & 2 & $85.83 \mathrm{ab}$ & $40.59 \mathrm{~b}$ & $90.00 \mathrm{a}$ & $50.92 \mathrm{a}$ \\
\hline 25 & 3 & $56.67 \mathrm{bcd}$ & $42.63 \mathrm{~b}$ & $54.17 \mathrm{bcd}$ & $42.77 \mathrm{a}$ \\
\hline 25 & 4 & 24.17 defg & $33.16 \mathrm{~b}$ & $13.33 \mathrm{fg}$ & $43.67 \mathrm{a}$ \\
\hline 30 & 1 & $95.00 \mathrm{a}$ & $40.98 \mathrm{~b}$ & $100.00 \mathrm{a}$ & $39.18 \mathrm{~b}$ \\
\hline 30 & 2 & 30.83 defg & $42.12 \mathrm{~b}$ & $74.17 \mathrm{abc}$ & $42.20 \mathrm{~b}$ \\
\hline 30 & 3 & $2.50 \mathrm{~g}$ & $42.10 \mathrm{~b}$ & $18.33 \mathrm{efg}$ & $42.27 \mathrm{~b}$ \\
\hline 30 & 4 & $0.00 \mathrm{~g}$ & $47.87 \mathrm{ab}$ & $54.17 \mathrm{bcd}$ & $40.96 \mathrm{~b}$ \\
\hline
\end{tabular}

\section{CONCLUSIONS}

Storage of cocoa seeds by non-vacuum packaging showed a higher of germination compared to vacuum packaging in all temperature treatments. Storage with non vacuum packaging at a temperature $25^{\circ} \mathrm{C}$ showed a germination more than $85 \%$ for 2 weeks of shelf life, while storage of cocoa seeds at a temperature of $30^{\circ} \mathrm{C}$ had a germination of more than $85 \%$ for only 1 week shelf life. Storage of cocoa seed at $15^{\circ} \mathrm{C}$ showed the lowest of germination at treatment. Storage treatments of did not show effect to water content of cocoa seeds.

\section{REFERENCES}

Adu, M.O.; T. Cobbinah; P.A. Asare; D.O. Yawson $\&$ K.J. Taah (2016). Demulcilaging freshly stored seeds of cocoa (Theobroma cacao L.) improves seedling emergence and growth. Journal of Botany, 2017, 1-10.

Bewley, J.D. \& M. Black (1985). Seed Physiology of Development and Germination. Plenum Press. New York and London.

Budiarti, T. (1990). Konservasi benih rekalsitran. p. 56-68. In: Keluarga Benih. Proceeding Seminar Sehari Persoalan Benih di Indonesia. Darmaga, Bogor.

Chang, S.M. \& J.M. Sung (1998). Deteriorative changes in primed sweetcorn seeds during storage. Seed Science Technology, 26, 613-626. 
Chiu, K.Y.; C.L. Chen \& J.M. Sung (2002). Effect of printing temperature on storability of primed sh-2 sweet corn seed. Crop Science, 42, 1996-2003.

Copeland, L.O. \& M.B. DcDonald (2001). Principles of Seed Science and Technology. Second Edition. Macmillan Publishing Company. New York.

Esrita (2009). Studi anatomi embrio benih kakao pada beberapa kadar air benih dan tingkat pengeringan. Jurnal Agronomi, 13, 1410-1939.

Gairola, K.C.; A.R. Nautiyal \& A.K. Dwivedi (2011). Effect of temperatures and germination media on seed germination of Jatropha curcas Linn. Advances in Bioresearch, 2, 66-71.

Halimursyadah (2012). Pengaruh kondisi simpan terhadap viabilitas dan vigor benih Avicennia marina (Forsk.) Vierh. pada beberapa periode simpan. Jurnal Agrotropika, 17, 43-51.

Ilyas, S. (2010). Ilmu dan Teknologi Benih. Institut Pertanian Bogor. Bogor.

Kuswanto, H. (2003). Teknologi Pemrosesan, Pengemasan, dan Penyimpanan Benih. Kanisius. Yogyakarta.

Maemunah, E.; Adelina \& I.Y. Daniel (2009). Vigor benih kakao (Thebroma cacao L.) pada berbagai lama penyimpanan dan invigorasi. Jurnal Agroland, 16, 206-212.

Purwanti, S. (2004). Kajian suhu ruang simpan terhadap kualitas benih kedelai hitam dan kedelai kuning. Ilmu Pertanian, 11, 22-31.

Rahardjo, P. \& D.F.S. Hartatri (2010). Penggunaan acrylic acid sodium polymer dalam upaya mempertahankan viabilitas benih kakao (Theobroma cacao L.). Pelita Perkebunan, 26, 83-93.
Rahardjo (2011). Menghasilkan Benih dan Bibit Kakao Unggul. Penebar Swadaya.

Rahman, M.; M. Syed; A. Akter; M.M. Alam \& M.M. Ahsan (2014). Genetic variability, correlation and path coefficient analysis of morpgological traits in transplanted Aman Rice (Oryza sativa L.). AmericanEurasian Journal of Agricultural and Environmental Science, 14, 387-391.

Roberts, E.H. (1973). Predicting the storage life of seeds. Seed Science and Technology, 1,499-514.

Schmidt, L. (2000). Pedoman Penanganan Benih Hutan Tropis dan Sub Tropis. Direktorat Jenderal Rehabilitasi Lahan dan Perhutanan Sosial, Departemen Kehutanan. Jakarta.

Sukhes \& K.R. Chandrashekar (2013). Effect of temperature on viability and biochemical changes during storage of recalcitrant seeds of Vatica chinensis L. International Journal of Botany, 9, 73-79.

Sumampow, D.M.F. (2010). Viabilitas benih kakao (Theobroma cacao L.) pada media simpan serbuk gergaji. Soil Environment, 8, 102-105.

Sutopo, L. (2002). Teknologi Benih. Fakultas Pertanian, Universitas Brawijaya. Malang.

Umarani, R.; E.K. Aadhavan \& M. Faisal. (2015). Understanding poor storage potential of recalcitrant seeds. Current Science, 108, 2023-2034.

Zink, E. \& L.A. Rochelle (1964). The influence of humidity and temperature on viability of cocoa seeds in storage. Bragantia, $23,110-116$.

$* * 0 * *$ 